Note

\title{
LIPOXYGENASE ACTIVITY IN BRAZILIAN RICE CULTIVARS WITH VARIABLE RESISTANCE TO LEAF BLAST DISEASE $\left(^{\mathbf{1}}\right)$
}

\author{
SARDUL SINGH SANDHU $\left({ }^{2}\right)$; PAULO MAZZAFERA $\left({ }^{4}\right)$; LUIZ ERNESTO AZINI $\left({ }^{3}\right)$; \\ CÂNDIDO RICARDO BASTOS $\left({ }^{3}\right)$; CARLOS AUGUSTO COLOMBO $\left(3^{*}\right)$
}

\begin{abstract}
Eight rice lines viz. CNA 8983, IAC-1732, IAC-1733, IAC-1748, IAC-1736, IAC-201, Volano and Arborea were evaluated in greenhouse for resistance against the leaf blast disease caused by Magnoparthe gracea. Lines CNA 8983, IAC 1732, IAC 1733 and IAC 1748 showed satisfactory resistance against the blast fungus while IAC 1736 and IAC 201 were intermediate and Volano and Arborea susceptible. All lines did not have lipoxygenase activity increased by methyljasmonic acid, however enzyme activity showed a positive relationship with resistance.
\end{abstract}

Key words: blast resistance; Magnoparthe gracea; methyljasmonic acid; Oryza sativa.

\section{RESUMO}

\section{ATIVIDADE DE LIPOXIGENASE EM CULTIVARES BRASILEIRAS DE ARROZ COM VÁRIOS NÍVEIS DE RESISTÊNCIA A BRUSONE}

Oito linhagens de arroz (CNA 8983, IAC-1732, IAC-1733, IAC-1748, IAC-1736, IAC-201, Volano e Arborea) foram avaliadas em casa de vegetação para a resistência contra a brusone causada por Magnoparthe gracea. As linhagens CNA 8983, IAC 1732, IAC 1733 e IAC 1748 foram satisfatoriamente resistentes contra o fungo; IAC 1736 e IAC 201 foram intermediárias e Volano e Arbórea, suscetíveis. Em todas as linhagens não ocorreu atividade de lipoxigenase aumentada pela exposição ao ácido metiljasmônico, no entanto, a atividade enzimática mostrou correlação positiva com a resistência.

Palavras-chave: brusone, resistência, Magnoparthe grisea; ácido metil-jasmônico; Oryza sativa.

$\left({ }^{1}\right)$ Recept for publication in January 2nd, 2006 and accept in August 15, 2006.

$\left({ }^{2}\right)$ Department of Biological Sciences, R. D. University, Jabalpur, (MP), India.

$\left({ }^{3}\right)$ Instituto Agronômico, Av. Barão de Itapura 1481, Caixa Postal 28, 13020-902 Campinas (SP), Brasil. Email: ccolombo@iac.sp.gov.br (*Autor correspondente)

$\left({ }^{4}\right)$ Departamento de Fisiologia Vegetal, IB, Unicamp, Caixa Postal 6109, 13083-970 Campinas (SP), Brasil. 


\section{Introduction}

Plants have developed multiple defense strategies to avoid pathogen colonization. These resistance strategies may exist as chemical or physical constitutive barriers or they may comprise an inducible second line of defense. Certain chemical and biological treatments can induce susceptible plants to become systematically resistant to a subsequent inoculation with virulent pathogens (KESSMANN et al., 1994). This is known as Systemic Acquired Resistance (SAR) in which there is the involvement of the enzyme lipoxygenase (Lox) and jasmonic acid and derivatives such as methyljasmonic acid (MJ). Jasmonates are synthesized through the octadecanoid pathway, in which linolenic acid is converted into jasmonic acid by a multi-step process involving Lox (FARMER and RYAN, 1992).

Some of the essential elements of SAR have been characterized in well studied dicotyledonous model systems like Arabidopsis and tobacco (STICHER et.al., 1997). In contrast, there is paucity of knowledge on SAR in monocotyledonous plants. In rice, biological and chemical activating agents have been reported to be effective in inducing acquired resistance. Although LAR (Local Acquired Resistance) of treated leaves is well documented, induction of systematic resistance in monocots is still controversial. While some reports described the observation of SAR in rice (Smith and Metraux, 1991; Schweizer et al., 1998), other experiments succeeded in demonstrating LAR, but not SAR (MAuch and Dudler, 1993; Schweizer et al., 1997; MAUCH et al., 1998).

Several rice cultivars with durable blast (Magnoparthe grisea) resistance have been identified (Bonman and MacKill, 1988; MacKILl and Bonman, 1992) and these plants have been used as resistance donors in breeding programs. Major resistance genes have been successfully used for developing leaf blast resistance cultivars and several dominant resistance genes have been identified which confer complete blast resistance (Yu et al., 1987; MACKILL and BONMAN, 1992; NaQvi et al., 1995; NAQvi and Chattoo, 1996; Yu et al., 1996).

Breeding for leaf blast resistance in Brazilian rice cultivars showed that several factors are involved in the blast resistance. In a previous work we reported RAPD markers for blast resistance and susceptibility in three rice cultivars lines (SANDHU et al., 2003). Here we report that one of the parameter for blast resistance is Lox activity that although was not induced by MJ, it was always higher in resistant lines than in susceptible.
In the present study eight rice lines viz. CNA 8983, IAC-1732, IAC-1733, IAC-1748, IAC-1736, IAC201, Volano and Arborea were evaluated in field conditions for resistance against the leaf blast disease caused by Magnoparthe grisea. Lines Volano and Arborea were introduced from Italy in Brazil by Instituto Agronômico (IAC), in Campinas, and they are originally used to prepare risotto. CNA 8983 is a comercial variety from Empresa Brasileira de Pesquisa Agropecuária (EMBRAPA) and IAC 201 is a commercial variety released by IAC; IAC 1732, IAC 1733, IAC 1748, and IAC 1736 breeding lines.

Resistance was evaluated according Ou (1965 ou 3). Each material (5 g seeds) was sowed in $50 \mathrm{~cm}$ lines spaced by $10 \mathrm{~cm}$ and after every two lines a third line was sowed with a mixture of susceptible material. Externally, in the border of the experiment three lines were sowed with susceptible material. Fertilization was adjusted to $50 \mathrm{~kg} / \mathrm{ha} \mathrm{P} 2 \mathrm{O} 5$ at sowing and 240 $\mathrm{kg} \mathrm{ha}^{-1} \mathrm{~N}$ (1/3 at sowing, and 2/3 after 15 and 25 days of seedling emergence). Irrigation was provided once a day. The estimates of resistance were carried out after 45 days of seedling emergence, using a visual score ranging from 1 to 9 as suggested by the "Standard Evaluation System for Rice" (http:// www.knowledgebank.irri.org/ses/SES.htm). This scale is recommended only for nursery evaluations and it ranges from 0 (no lesions observed) to 9 (more than $75 \%$ of the leaf area affected by the disease). Evaluations were carried out in five experimental stations of the IAC at Pindamonhangaba, Capão Bonito, Monte Alegre do Sul, Mococa and Ribeirão Preto. Two replicates were used in each locality.

Lox activity was determined as described by SHImizu et al. (1990) using a Clark oxygen electrode (DelieU and WALKER, 1972). Leaves from induced and non-induced controls were ground with $100 \mathrm{mM} \mathrm{Na}$ phosphate buffer, $\mathrm{pH} 7.0$, containing $5 \mathrm{mM}$ 2-mercaptoethanol, and $10 \mathrm{mM}$ ascorbic acid, and centrifuged at $15,000 \mathrm{rpm}, 4^{\circ} \mathrm{C}$. The supernatant was recovered and filtered in PD-10 Sephadex G25 columns (Amershan-Pharmacia) using $25 \mathrm{mM} \mathrm{Na-}$ phosphate buffer, pH 7.0, as elution buffer. Leaf extracts were incubated with 100 ìm linoleic acid in $100 \mathrm{mM}$ sodium acetate buffer $\mathrm{pH}$ 6.5. Tween 20 was added to a final concentration of $0.1 \%$. Protein content was estimated in the extracts (BRADFORD, 1976) and the lipoxygenase activity expressed as nmoles $\mathrm{O}_{2} /$ min.mg protein.

Fifteen days old seedlings growing in plastic pots $(0.5 \mathrm{~L})$, with the third leaf expanded were used for MJ treatment. A cotton piece which received $25 \mu 1$ of MJ was left on the surface of the pot substrate and then the plants were covered with plastic bags (size 
$70 \mathrm{~cm} \times 90 \mathrm{~cm}$ ), which were tied to the plastic pot with a rubber band. Control plants were also placed in plastic bags but without MJ. After $24 \mathrm{~h}$, a second application of $25 \mu \mathrm{l}$ of MJ was made. After $24 \mathrm{~h}$ of the second MJ application the leaves were harvested and immediately stored in liquid nitrogen for Lox activity. The data were submitted to analysis of variance and means were compared by Tukey test at $5 \%$.

Eight rice lines viz. CNA 8983, IAC 1732, IAC 1733, IAC 1748, IAC 1736, IAC 201 Volano and Arboreae were evaluated for resistance against the blast disease (Table 1). A large variation was observed ranging from the highly resistant line CNA 8983 (score 1.0) to the highly susceptible lines Volano and Arborea (8.5 and 9.0, respectively). These later varieties have shown susceptibility for most of the rice fungal diseases in Brazil (Cândido R. Bastos, personal observation).

As depicted in the table 1 there was not significant induction of Lox activity by MJ application. However, it is evident that resistance was associated with the enzyme activity, as a high activity was strongly associated with resistance, except for the Volano line, probably due to its genetic background very divergent.

Table 1. Evaluation of rice lines resistance to blast disease and lipoxygenase activity of non-induced and induced plants with methyljasmonic acid

\begin{tabular}{lccc}
\hline \multirow{2}{*}{ Lines } & $\begin{array}{c}\text { Disease } \\
\text { Rates }\end{array}$ & \multicolumn{2}{c}{$\begin{array}{c}\text { Lipoxygenase activity } \\
\text { (nmoles } \mathrm{O}_{2} / \text { min.mg protein) }\end{array}$} \\
\cline { 2 - 4 } & & MJ non-treated & MJ treated \\
\hline CNA 8993 & $1.0 \mathrm{a}^{\# 2}$ & $0.327 \mathrm{a}$ & $0.316 \mathrm{c}$ \\
IAC 1732 & $1.3 \mathrm{ab}$ & $0.337 \mathrm{a}$ & $0.407 \mathrm{~b}$ \\
IAC 1733 & $1.3 \mathrm{ab}$ & $0.309 \mathrm{ab}$ & $0.420 \mathrm{a}$ \\
IAC 1748 & $1.8 \mathrm{~b}$ & $0.267 \mathrm{~b}$ & $0.287 \mathrm{~d}$ \\
IAC 1736 & $4.8 \mathrm{c}$ & $0.144 \mathrm{c}$ & $0.237 \mathrm{e}$ \\
IAC 201 & $4.8 \mathrm{c}$ & $0.145 \mathrm{c}$ & $0.172 \mathrm{f}$ \\
Volano & $8.5 \mathrm{~d}$ & $0.272 \mathrm{~b}$ & $0.318 \mathrm{c}$ \\
Arborea & $9.0 \mathrm{~d}$ & $0.169 \mathrm{c}$ & $0.178 \mathrm{f}$ \\
\hline
\end{tabular}

(1)Values for each treatment are means of three replicates.

$\left({ }^{2}\right)$ Means followed by different letters in the column are different by Tukey test at $5 \%$.

In rice, Lox activity has been described to correlate positively with resistance to blast disease, since the octadecanoid pathway is activated after infection by the fungus (OHTA et al., 1991). However, high Lox activity may be constitutive in plants resistant to pathogens but with an additional increase upon infection (DEVI et al., 2000) or exposition to chemical inducers such as jasmonic acid and derivatives such as MJ (SchAFFrATH et al., 2000). This might be explained by expression of genes coding for the same enzyme - isozymes (DEVI et al., 2000; BUNKER et al., 1995) and Lox genes being expressed in specific tissues (STEINER-LANGE et al., 2003). A chloroplast rice Lox was shown to be induced by several chemical inducers but not by inoculation with compatible and incompatible races of the rice blast fungus and the no host pathogen Pseudomonas syringae pv. syringae (SchafFrath et al., 2000).

In conclusion, although not induced by MJ, Lox might be a screening factor for blast disease resistance in rice.

\section{ACKNOWLEDGMENTS}

S. S. Sandhu thanks CNPq (Brazil) and TWASUNESCO (Italy) for financial support to visit IAC, Campinas, Brazil. P. Mazzafera thanks CNPq (Brazil) for a research fellowship.

\section{REFERENCES}

BONMAN, J.M., YEH, W.H., BANDONG, J.M. Assessment of partial resistance to blast in lowland rice cultivars. Phytopathology, St. Paul, v.76, p. 1105-1105, 1986.

BONMAN, J.M., MACKILL D.J. Durable resistance to rice blast disease. Oryza, Cuttach, v.25, p. 103-110, 1988.

BRADFORD, M.M. A rapid and sensitive method for quantification of microgram quantities of protein utilising the principle of protein-dye binding. Analytical Biochemistry, Duluth, v.72, p. 248-251, 1976.

BUNKER, T.W., KOETJE, D.S., STEPHENSON, L.C., CREELMAN, R.A., MULLET, J.E., GRIMES, H.D. Sink limitation induces the expression of multiple soybean vegetative lipoxygenase mRNAs while the endogenous jasmonic acid level remains low. Plant Cell, Baltimore, v.7, p. 1319-1331, 1995.

DELIEU. T., WALKER, D.A. An improved cathode for the measurement of photosynthetic oxygen evolution by isolated chloroplasts. New Phytologisty, Cambridge, v.71, p. 201-225, 1972.

DEVI, P.U.M., REDDY, P.S., RANI, N.R.U., REDDY, K.J., REDDY, M.N. Lipoxygenase metabolites of alpha-linolenic acid in the development of resistance in pigeon pea, Cajanus cajan (L.) Millsp, seedlings against Fusarium udum infection. European Journal of Plant Pathology, v.106, p. 857-865, 2000.

FARMER, E.E., RYAN, C.A. Octadecanoid precursors of jasmonic acid activate the synthesis of wound-inducible proteinase inhibitors. Plant Cell, Baltimore, v.4, p. 129-134, 1992.

KESSMANN, H., STAUB, T., HOFFMANN, C., MAETZKE, T., HERZOG, J., WARD, E., UKNES, S., RYALS, J. Induction of systemic acquired disease resistance in plants by chemicals. Annual Review of Phytopathology, Palo Alto, v.32, p. 439-459, 1994. 
MACKILL, D.J., BONMAN, J.M. Inheritance of blast resistance in near isogenic lines of rice. Phytopathology, St. Paul, v.82, p. 746-759, 1992.

MAUCH, F., DUDLER, R. Differential induction of distinct glutathione-S-transferase of wheat by xenobiotics and by pathogen attack. Plant Physiology, Sofia, v.102, p. 11931201, 1993.

MAUCH, F., REIMMANN, C., FREYDL, E., SCHAFFRATH, U., DUDLER, R. Characterization of the rice pathogen-related protein Rirla and regulation of the corresponding gene. Plant Molecular Biology, Dordrecht, v.38, p. 577-586, 1998.

NAQVI, N.I., CHATTOO, B.B. Development of sequence characterized amplified region (SCAR) based indirect selection method for dominant blast-resistance gene in rice. Genome, Otawa, v.39, p. 26-30, 1996.

NAQVI, N.I., BONMAN, J.M., MACKILL, D.J., NELSON, R.J., CHATTOO, B.B. Identification of RAPD markers linked to a major blast resistance gene in rice. Molecular Breeding, v.1, p. 341-348, 1995.

OHTA, H., SHIDA, K., PENG, Y.L., FURUSAWA, I., SHISHIYAMA, J., AIBARA, S., MORITA, Y. A lipoxygenase pathway is activated in rice after infection with the rice blast fungus Magnaporthe grisea. Plant Physiology, Sofia, v.97, p. 9498, 1991.

OU, S.H.Varietal reactions of rice to blast. In: THE RICE BLAST DISEASE. SYMPOSIUM AT THE INTERNATIONAL RICE RESEARCH INSTITUTE (IRRI), July 1963, Baltimore. Proceedings... The Johns Hopkins Press, v.1. p.223-234. (no texto 1965)

SANDHU, S.S., COLOMBO, C., BASTOS, C.R., SIQUEIRA, W.J. DNA tagging of blast resistant gene(s) in three Brazilian rice cultivars. Genetics and Molecular Biology, v.26, p. 473-477. 2003.

SCHAFFRATH, U., ZABBAI, F., DUDLER, R. Characterization of RCI-1, a chloroplastic rice lipoxigenase whose synthesis is induced by chemical plant resistance activators. European Journal of Biochemistry, v.267, p. 5935-5942, 2000.
SCHWEIZER, P., BUCHALA, A., DUDLER, R., METRAUX, J.P. Induced systemic resistance in wounded rice plants. Plant Journal, v.14, p. 475-481, 1998.

SCHWEIZER, P., BUCHALA, A., SILVERMAN, P., SESKAR, M., RASKIN, I., METRAUX, J.P. Jamonate-inducible genes are activated in rice by pathogen attack without a concomitant increase in endogenous jasmonic acid levels. Plant Physiology, Sofia, v.114, p. 79-88, 1997.

SHIMIZU, T., HONDA, Z-.I., MIKI, I., SEYAMA, Y., IZUMI, T., RADMARK, O., SAMUELSON, B. Potato arachidonate 5lipoxygenase: purification, characterization, and preparation of 5(S)-hydroperoxyeicosatetraenoic acid. Methods in Enzymology, Sofia, v.187, p. 296-306, 1990.

SMITH, J.A., METRAUX, J.P. Pseudomonas syringae pathovar syringae induces systemic resistance to Pyricularia oryzae in rice. Physiological and Molecular Plant Pathology, v.39, p.451-461, 1991.

STEINER-LANGE, S., FISCHER, A., BOETTCHER, A., ROUHARA, I., LIEDGENS, H., SCHMELZER, E., KNOGGE, $W$. Differential defense reactions in leaf tissues of barley in response to infection by Rhynchosporium secalis and to treatment with a fungal avirulence gene product. Molecular PlantMicrobe Interactions, St. Paul, v.16, p. 893-902, 2003.

STICHER, L., MAUCH-MANI, B., MÉTRAUX, J.P. Systemic acquired resistance. Annual Review of Phytopathology, Palo Alto, v.35, p.235-270, 1997.

YU, Z.H., MACKILL, D, J., BONMAN, J.M. Inheritance of resistance to blast in some traditional and improved rice cultivars.Phytopathology, St. Paul, v.77, p. 323-326,1987.

YU, Z.H., MACKILL, D, J., BONMAN, J.M., MCCOUCH, R.C.,GUIDERDONI,E., NOTTEGHEM, J.L.,TANKSLEY, S.D. Molecular mapping of genes for resistance to rice blast (Pyricularia gresea Sacc.). Theoritical and Applied Genetics, v.93, p.859-863, 1996. 